\title{
Some aspects of venereal diseases in Greenland
}

\author{
ELLIS FROM \\ From the Department of Dermatology and Venereology, University of Aarhus, Marselisborg Hospital, \\ Aarhus, Denmark
}

SUMMARY For many years venereal diseases have been a major problem in Greenland. Since the early 1950s gonorrhoea has been widely prevalent; in the middle of the 1960s the incidence increased rapidly. Since the early 1970s syphilis has become widespread in the population, and in 1977 an epidemic of chancroid occurred. The high figures for venereal diseases are basically due to the social change towards a modern industrial society. Improvements in the health services could be made by encouraging health education on venereal diseases, training Greenlander health personnel, and appointing a venereologist.

\section{Introduction}

Greenland is the world's largest island with a surface area of just under $2 \cdot 2$ million $\mathbf{k m}^{2}$, about $80 \%$ of which is covered by the ice cap. The distance from north to south is about $2700 \mathrm{~km}$-that is, as far as from southern Norway to Tunisia. The distance from east to west is $1050 \mathrm{~km}$, or as far as from Copenhagen to Paris. The Greenlanders have a language of their own; many young Greenlanders also speak Danish.

The population is almost 50000 , of whom nearly 10000 are from Denmark. Before the second world war the inhabitants were distributed equally between the towns and settlements, but during recent years the population has concentrated in the towns, so that about $75 \%$ now live there.

In previous years, the population lived on hunting -especially seal hunting - and the standard of living was determined mainly by the efforts of the individual hunter. On the amendment of the Danish constitution in 1953, after which Greenland acquired the status of part of the Kingdom of Denmark with equal rights, special importance was attached to fishing. By Danish capital transfers, efforts have been made to change Greenland into a modern industrial society with social welfare benefits. This has resulted in a considerable improvement in the standard of living and an explosive increase in the population, which has now been curbed by intensive contraceptive programmes.

Address for reprints: Dr E From, Department of Dermatology and Venereology, Marselisborg Hospital, DK 8000 Aarhus C, Denmark

Received for publication 17 September 1979
Greenland has a free health service, including free hospital treatment and free medicines. Greenland is divided into 16 medical districts, each served by up to five doctors. In each district there are nurses, mainly from Denmark, and a native nursing staff, all of whom have received a three-year hospital training in Greenland.

In the spring and summer of 1977 , I went to Greenland to evaluate the prevalence of venereal diseases there. I visited 14 of the 16 medical districts; the remaining two districts were remote hunters' districts, in which venereal disease was not a problem. The population over 13 years of age in these two districts consisted of $\mathbf{4 4 2}$ men and 416 women-that is, $2 \cdot 3$ and $2 \cdot 6 \%$ respectively of the entire male and female population over 13 years. ${ }^{1}$

\section{Gonorrhoea}

For many years the venereal diseases have been a major problem in Greenland and the fight against them has put a considerable strain on the health services. It was more than 140 years since the Danish colonisation of Greenland in 1721 before venereal disease in Greenlanders was first observed. The first case was one of gonorrhoea among women living in the neighbourhood of Ivigtut, the cryolite mine in southern Greenland. ${ }^{2}$ During the next 50 years only a few cases were reported. From 1913 to 1940, the prevalence of gonorrhoea varied greatly from year to year. A remarkably high percentage of infected patients $(68 \%)$ were married and $35 \%$ were over 30 years of age. Nearly as many women were affected as men; of the latter, many were both elderly and married. ${ }^{3}$ 
Since 1945 the prevalence of gonorrhoea has been higher in Greenland than in Denmark. From 1966 to 1974 (when nearly 12000 cases were reported) the incidence rose steeply (Fig 1). The increase has been most pronounced in the 16-19 age range, particularly among girls. The large number of repeated infections is a characteristic feature of the gonorrhoea morbidity in Greenland. Of the teenagers, $57 \%$ are reinfected within one year; $31 \%$ of girls and $11 \%$ of boys are treated more than twice a year for gonorrhoea. ${ }^{4}$ During the last few years the number of reported cases has fallen. During the first nine months of 1977, a total of 7608 cases were reported in the 14 medical districts that I visited-4533 in men and 3075 in women. The distribution per 1000 population by age and sex is given in Table $I$. The high prevalence in young women is remarkable. Furthermore, gonorrhoea was diagnosed in three boys and nine girls aged from 7 to 12 years. In the other two medical districts, there were 35 cases of gonorrhoea in men and $\mathbf{4 0}$ cases in women.

\section{Syphilis}

Until 10 years ago, Greenland was largely free of syphilis. Small localised outbreaks had occurred in 1872,1947 , and 1965 in southern Greenland. ${ }^{5} 6$ That Greenland could previously be kept free of syphilis

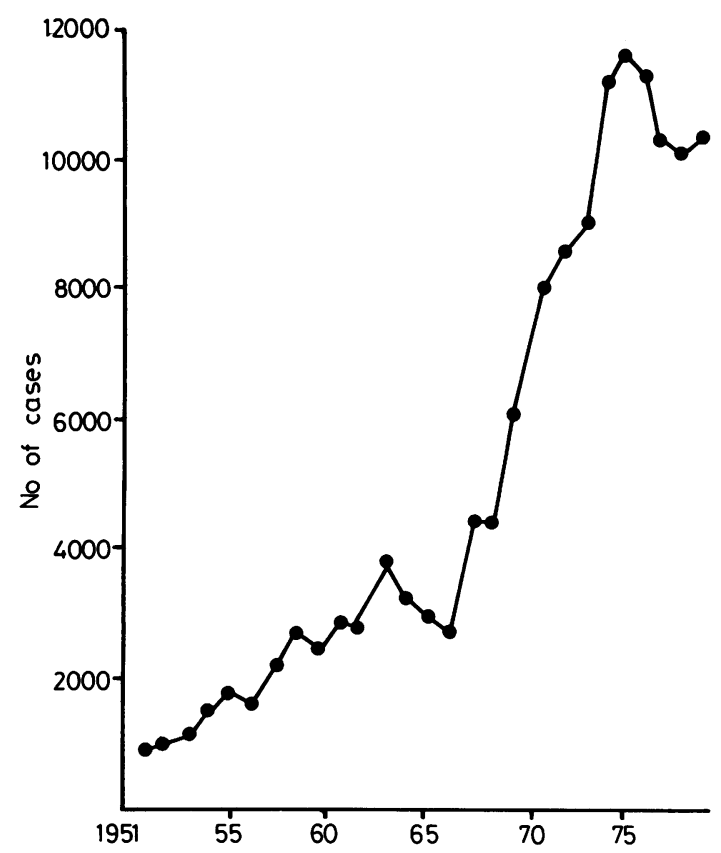

FIG 1 Annual number of reported cases of gonorrhoea in Greenland
TABLE I Age and sex distribution of number of reported cases of gonorrhoea, syphilis, and chancroid per 1000 population (1 January to l October 1977)

\begin{tabular}{|c|c|c|c|c|c|c|c|c|}
\hline \multirow{3}{*}{ Disease } & \multicolumn{8}{|c|}{ Age group (years) } \\
\hline & \multicolumn{2}{|l|}{$13-15$} & \multicolumn{2}{|c|}{$16-19$} & \multicolumn{2}{|c|}{$20-44$} & \multicolumn{2}{|c|}{45 or ove } \\
\hline & $M$ & $F$ & $M$ & $F$ & $M$ & $F$ & $M$ & $F$ \\
\hline $\begin{array}{l}\text { Gonorrhoea } \\
\text { Syphilis } \\
\text { Chancroid }\end{array}$ & $\begin{array}{l}21 \\
1 \\
0.5\end{array}$ & $\begin{array}{r}93 \\
12 \\
7\end{array}$ & $\begin{array}{r}386 \\
17 \\
36\end{array}$ & $\begin{array}{r}565 \\
48 \\
35\end{array}$ & $\begin{array}{r}352 \\
22 \\
28\end{array}$ & $\begin{array}{r}217 \\
20 \\
17\end{array}$ & $\begin{array}{r}42 \\
6 \\
6\end{array}$ & $\begin{array}{r}21 \\
5 \\
3\end{array}$ \\
\hline
\end{tabular}

was undoubtedly due to its only connection with the outside world being by ship from Denmark. Medical examination of all crews was compulsory before departure to Greenland. The voyage was so long that the incubation period for syphilis was usually exceeded before the ships arrived and any signs of syphilis on arrival led to quarantine of the person concerned.

However, after 1969 an increasing number of cases occurred, and during the following few years this increase was exponential (Fig 2). During the first nine months of 1977 a total of 577 cases-284 in men and 293 in women-were reported in the 14 medical districts visited. The sex and age distribution per 1000 population is shown in Table I. Again, the high prevalence among girls aged 13-19 years is remarkable. In addition, one case of congenital syphilis was detected in a newborn baby and two cases of acquired syphilis were diagnosed in boys aged 8 and 9 years. In the other two medical districts, there were two cases of syphilis.

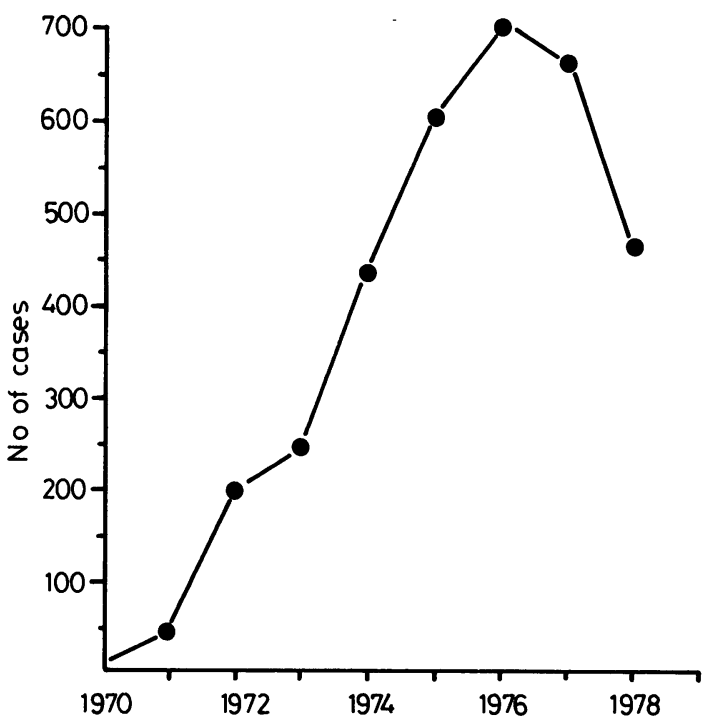

FIG 2 Annual number of reported cases of syphilis in Greenland 
In 1977 the increase in the incidence of syphilis suddenly stopped and a decline occurred (Fig 2). Several factors have presumably contributed to this decline. One important factor was the epidemic of chancroid, which alarmed the population. The painful genital ulcers caused many patients to seek medical advice early, which led to a more prompt diagnosis of syphilis. Another important factor is that during recent years epidemiological treatment has consistently been given to all contacts of syphilis, thus causing a decrease in the pool of infectious syphilis from which the infection is contracted.

Within the last two years the rapid plasma reagin test has been widely used in Greenland, thus making it possible to establish the diagnosis at an earlier stage and to shorten the infectious period. Previously, the diagnosis depended on the result of the Wassermann reaction-which is performed at Statens Serum Institute in Copenhagen-and, when weather was bad, two to three weeks could pass before treatment could be started, which obviously prolonged the infectious period. New darkground equipment in the various medical districts has also contributed to an earlier diagnosis and a shortening of the infectious period.

So far, no cases of tertiary syphilis have been encountered. However, many hidden cases of syphilis do exist. Screening of the adult population, using the Wassermann reaction, carried out in three towns during the spring of 1977 showed that nearly $1 \%$ of adults had previously had unrecognised syphilis. Patients of all different age and socioeconomic groups, as well as of marital state, were affected. This confirms the old venereological truth that syphilis spreads diffusely and secretly among the whole population. However, the figure of $1 \%$ is low compared with the very high figures shown by screening programmes in some settlements in southern Greenland in 1976; about 40 cases were detected, although only 300 persons were investigated.

\section{Chancroid}

We do not know when chancroid came to Greenland, but presumably it was in 1976. For some years, Greenland has had rapid communications with the outside world, both by ship and by air. In 1976 patients with painful genital ulcers-in some cases associated with abcesses in the groin-were found in some towns on the west coast. Gradually it became clear that the patients had chancroid. The epidemic spread rapidly in Godthåb in March 1977 and in the following months in southern Greenland (Fig 3). In the summer months a few cases occurred in the Disko area. No cases occurred in northern or eastern Greenland, presumably because of the longer travelling time.

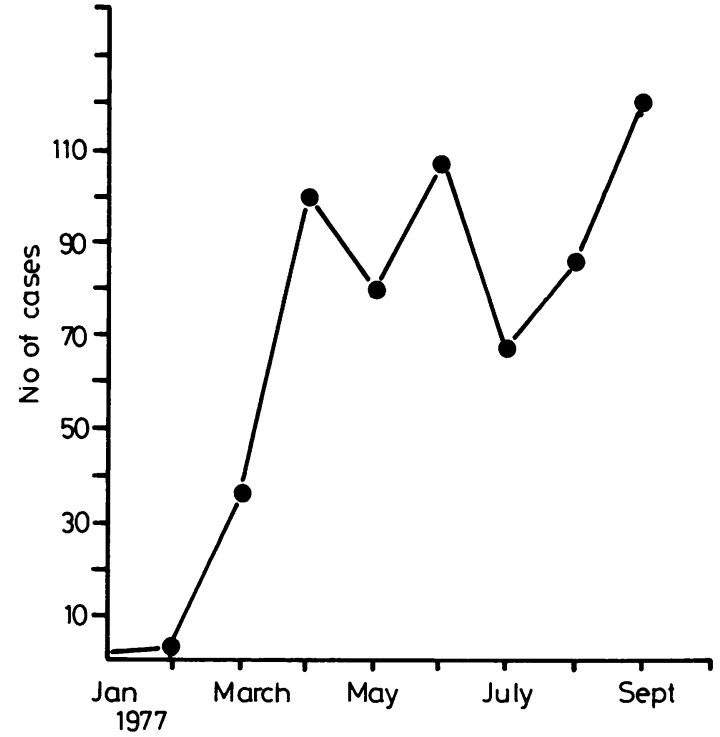

FIG 3 Number of reported cases of chancroid in Greenland each month from I January to 1 October 1977

In the first nine months of 1977 , a total of 605 cases were reported-379 in men and 226 in women (a male-to-female ratio of $1 \cdot 7: 1$ ). This ratio is much lower than that usually reported ${ }^{7}$ and suggests equal partner change in men and women. The sex and age distribution per 1000 population is shown in Table I. Again, the high figures for girls aged 13-19 years are remarkable. In 1977, 975 cases were reported in Greenland. A drop in the monthly figures for chancroid started in November 1977 and continued in 1978; only 488 cases were reported in that year. A cause of the steep fall in the number of reported cases is undoubtedly due to the fact that the disease is very painful. A public debate on the disease and effective efforts to trace contacts has also been of importance.

\section{Other sexually transmitted diseases}

Lymphogranuloma venereum has not yet been encountered in Greenland, but nongonococcal urethritis, nongonococcal salpingitis, Reiter's disease, genital herpes, genital warts, and scabies are frequently seen.

\section{Comments}

The question may be asked why venereal diseases are so common in Greenland. During recent years, many factors have contributed to the spread of venereal diseases. The basic cause of the very high figures for venereal diseases is the social problems caused by 
change to a modern industrial society. The Greenlanders have not been given time to keep pace with developments; they have been mainly onlookers. This has given rise to problems of violence, promiscuity, and abuse of alcohol. Drinking is excessive; during recent years the annual consumption of alcohol has been well over 18 litres of $100 \%$ alcohol per person over 14 years of age. This year, politicians in Greenland have tried to curb the abuse of alcohol by introducing rationing. Among many other causes of the spread of venereal diseases is the concentration of the population, with many young people at a sexually active age, in the towns. This urbanisation has given rise to large youth groups, in which the individual members know less of the others than before, which makes the tracing of contacts difficult. The population over 13 years distributed by age group and by sex is given in Table II. ${ }^{1}$ There are about 3500 more men than women, mainly due to the importation of manpower from Denmark. It is active men, mainly aged 20-44 years, who exert sexual pressure inevitably on the young Greenlander women.

All these factors are outside the influence of the national health service. During recent years, diagnostic aids have improved, but the health service may introduce further improvements by training personnel and by intensifing the dissemination of information on venereal diseases in the population. The appointment of a venereologist is required, not only for the solution of the many diagnostic and therapeutic problems but also to take care of the training, especially of Greenlander personnel. After training, these people must play an active part in health education, especially in schools and youth clubs. Well-trained Greenlander health workers, acting as "bare-foot doctors" under the guidance of the venereologist, can do a lot in the control of venereal diseases.

TABLE II Age and sex distribution of population of 13 years or over. (In brackets persons not born in Greenland.)

\begin{tabular}{llllll}
\hline \multicolumn{5}{c}{ Age group (years) } \\
\cline { 2 - 6 } Sex & $13-15$ & $16-19$ & \multicolumn{1}{l}{$20-44$} & 45 or over \\
\hline Male & $1998(121)$ & 2233 & $(81)$ & $11297(4438)$ & $3855(781)$ \\
Female & $2017(123)$ & $2057(112)$ & $8092(1663)$ & $3716(172)$ \\
\hline
\end{tabular}

\section{References}

1. Groenlands Befolkning. Danmarks Statistik. Copenhagen, 1977.

2. Lange C. Bemaerkninger om Groenlands Sygdomsforhold. Bibliot Laeger 1864; 5RK8BD: 15-64.

3. Berthelsen A. Groenlandsk medicinsk statistik og nosografi. In: Meddelelser om Groenland 1935-1943; Bd 117:III Copenhagen: Reitzel.

4. Olsen GA. Seksuel adfaerd blandt ungdom i Groenland. Copenhagen: Institut for Socialmedicin, Publication No 4, 1974.

5. Marcussen PV, Rendal J. A study of syphilis and sexual habits in Greenland. Amer J Syph 1950; 34: 144-52.

6. Olsen GA. Syphilisepidemien i Sydgroenland i 1965. Ugeskr Laeger 1966; 128: 1071-6.

7. Willcox RR. A Textbook of Venereal Diseases. London: William Heinemann, 1950. 